\title{
Service experiences beyond the direct use: Indirect customer use experiences of smartphone apps
}

Dube, A. and Helkkula, A. (2015), Journal of Service Management, Vol. 26 No. 2, pp. 224-248

\section{Post-print version (final draft post-refereeing)}

Purpose: This paper examines customers' use experiences in a smartphone app context. Apps have emerged as popular tools among marketing practitioners. In service research, however, smartphone apps, and their customers' use experiences, have received limited attention.

Methodology: This paper provides a conceptual overview and draws on an empirical twophase study comprising a) diary narratives of using a specific app and b) semi-structured interviews on the use of multiple apps by app users.

Findings: Results show that indirect use experiences play an important role in the holistic service experience. Compared with direct experiences, indirect use experiences do not require the actual use of apps or direct contact with the user. Also the context, such as the time and location of app use, is important for both direct and indirect use experience.

Research implications: This paper highlights indirect use experiences as a vital component of service experiences and encourages researchers not to restrict use experiences to direct use only. Indirect use experiences enable managers to gain deep insights into the everyday use experiences of current and potential customers.

Originality: First, previous research on service experience has mainly focused on direct use experiences. This study highlights that indirect use experiences are an important part of the service experience. Second, to the best of our knowledge, this research is the first attempt to investigate the use experiences of smartphone apps in a service marketing context.

Keywords: Service Experience, Use Experience, Smartphone Apps, Phenomenology, Valuein-use, Co-creation

Article Classification: Research Paper 


\section{Introduction}

The mobile application (app) business has become increasingly significant in recent years. Smartphone apps are software application programs that are designed to run on specific operating system platforms. With the emergence of smartphones during the last decade, apps have become the key interaction and service provision mechanism between the smartphone and the customer. Apps provide several services and have an impact through their service experiences on the everyday lives of their users (Dube, 2014). For example, Apple offers more than 750,000 apps to its customers via its App Store (Monti, 2013). Available in both priced and free versions, apps have largely replaced the use of other mobile-based services.

Recently, apps have started to attract research attention in the marketing and managerial literature, particularly in the research in branding (Bellman et al., 2011) and consumer adoption (Racherla et al., 2012), where their effects on brands and product stickiness has been investigated. A growing body of managerial and marketing research has examined the effect of apps on several issues, such as web-usage (Kellogg, 2011), customer service jobs (Troianovski, 2013), and national and trans-national economies (European Commission, 2014). However, although service experiences have gained some research attention in recent years (Ostrom et al., 2010); service experiences of smartphone apps, and use experiences in particular, have not yet been adequately researched. To address this research gap, the purpose of this paper is to examine customers' use experiences in the smartphone app context. In the empirical part of the study, we address the following research question: What types of use experiences do customers have when they use smartphone apps?

In this study, we draw on phenomenological experience in a service context, namely service experience. This concept has its origins in the paradigm shift away from researching consumer behavior from a logical, rationalistic perspective to an experiential, subjective interpretation (Holbrook and Hirschman, 1982). This phenomenological characterization also has support in the evolution of service-dominant (S-D) logic (Vargo and Lusch, 2008, 2004), which focuses on the service experience. In recent research, service experiences are seen as a core element in the emergence of experiential value. 
The paper is divided into the following sections: first, theoretical reviews of both service experience and use experience literature are presented. Next, the methodology of the study is explained. This section outlines the two-phase study: the first phase includes diary narratives, and the second phase involves interviews with respondents on app-related use experiences. We then present the findings of the study. Two main types of use experiences emerged from the data analysis, which we name as direct and indirect use experiences. Direct use experiences include the actual use of apps and thus direct user contact. In contrast, indirect use experiences include those that do not require the actual use of apps or direct user contact. As use experiences form part of holistic service experience, both direct and indirect use contribute to customers' service experiences. Service experience research has, however, extensively focused on service experiences from direct use (Sandström et al., 2008; Edvardsson et al., 2010). In contrast, indirect service use, where customers are not in direct contact with service, is scarcely highlighted in investigating service experiences. Finally, we discuss the significance of app-related use experiences for researchers and managers, particularly of indirect use experiences.

\section{Literature review}

The word "experience" has multiple connotations as it is used in different contexts. Employing "experience" as a verb ("I have/he has experienced...") leads to a phenomenological characterization of the concept, in which the activity of experience is uniquely personal. On the other hand, the noun "experience" ("In my experience. .." or "I have learnt from my experiences. ..") refers to the knowledge aspect of experience (tacit or explicit). In previous research, scholars have used similar conceptualizations of experience, including Carù and Cova (2003, pp. 269-270), who presented a compilation of conceptualizations of experience from different research streams: natural sciences (experiment experience), philosophy (self-transformation from experience), sociology and psychology (subjective and cognitive experience), and anthropology (experience as a way of living).

Despite such differences, all these conceptualizations of experience are used to express the subjectivity of human perception. In this paper, we first discuss experiences in the service context, and then emphasize a specific type of service experience - the use experience of smartphone apps. 


\subsection{Evolution of the service experience concept}

The concept of service experience is an old, but relatively underdeveloped, concept in the marketing literature. The reason for this paradox lies in the way service experience has been hidden beneath other more focused concepts of services marketing, such as service quality, customer satisfaction, service environment and value-in-use. The genesis of the concept of service experience lies in the seminal article by Holbrook and Hirschman (1982), which attacked the rational, information-processing view of consumption in consumer behaviour. The article stressed an experiential view of consumption, seeing it as "a primarily subjective state of consciousness with a variety of symbolic meanings, hedonic responses, and aesthetic criteria" (Holbrook and Hirschman, 1982, p. 132). This experiential view of consumption was a theoretical milestone, after which the view of consumption as a hedonic phenomenon gained increasing acceptance among marketing researchers.

Service marketing scholars also drew inspiration from the experiential view and applied it to consumption in the service setting. Consequently, service experience, or experience in a service setting (Helkkula, 2011), debuted in the context of hedonic "Disney Land" services (see Carù and Cova, 2003; Pine and Gilmore, 1999). Indeed, in the 1990s, service experience research focused on hedonic services (e.g., river rafting) (Arnould and Price, 1993). The two characterizations of service experience as "extraordinary" (Abrahams, 1986; LaSalle and Britton, 2003) and "memorable" (Pine and Gilmore, 1999) have received extensive attention in the literature.

The conceptualization of service experience then broadened from this restrictive approach; and was researched as a new economic offering for gaining competitive advantage in the experience economy. In parallel with the service experience research, economic sciences in general and marketing in particular focused on experiences as economic objects, which led to the development of the concept of the experience economy (Pine and Gilmore, 1998, 1999) and the research stream of experiential marketing (Schmitt, 1999). This characterization of experience as an economic offerings for competitive advantage argued for bringing the concept of service experience out of its twin niches of "hedonic" and "memorable" into the world of "normal, day-to-day service experiences" (Edvardsson et al., 2005, p. 149). These 
two specific characterizations of hedonic and memorable experiences, however, have not been broadened with the same pace, and the latter has lagged behind the former.

Researchers have reached agreement on the omnipresence of service experiences, regardless of their hedonic or non-hedonic nature. Edvardsson et al. (2005, p. 151), referring to Johnston and Clark (2001), characterize service experience as a process that creates the customer's cognitive, emotional and behavioural responses, resulting in a "mental mark" or memory. This characterization brings service experiences into the customer realm and is based on the idea that service experiences occur in all types of service encounters, and they may even occur prior to (Edvardsson et al., 2010) and post service encounters (Sandström et al., 2008). Multiple characterizations of service experiences were developed in the early 2000s, treating them as processes that were developed in the customer realm, which were, nevertheless, manageable by the service provider (Pine and Gilmore, 1998). Service experiences have also been treated as outcomes of service processes, and their relationships with other marketing concepts were a dominant research theme in this period. Helkkula (2011) proposed a threefold framework for characterizing the concept of service experience. She delineated service experience as (a) a process, (b) an outcome, and (c) a phenomenon.

\subsubsection{Service experience as a process}

The process approach of characterizing the service experience focuses on the dimensions or process elements of service experience, as well their functioning and management. These dimensions, or "architectural elements" (Helkkula, 2011) are associated with the process of service provision, including interaction with employees, technology and facilities (Edvardsson et al., 2010, p. 313). Researchers following this characterization of service experience have produced both empirical and conceptual works that view the customer as the subject of the experience.

Bitner's (1992) seminal work on the "servicescape" has inspired researchers to investigate the management techniques of service experience, such as "service experience design" (Pine and Gilmore, 1998), "service experience blueprinting" (Patricio et al., 2011), "hyper-reality" (Edvardsson et al., 2005), and "experience room" (Edvardsson et al., 2005, 2010). All these concepts rest on the principle that the service environment determines and creates favorable experiences (Bitner, 1992; Lovelock and Wirtz, 2007; Reimer and Kuehn, 2005). The effective management of the architectural elements can lead to favorable service experiences 
for the customers (Edvardsson et al., 2005; Pareigis et al., 2012). The latter assumption is, however, is made with caution, because researchers who followed this characterization of service experience also agree that service experiences are co-created with the customer (Pareigis et al., 2011; Pine and Gilmore, 1998).

\subsubsection{Service experience as an outcome}

Service experience is characterized as not only a process but also an outcome (Helkkula, 2011). In this characterization, service experience has two outcome dimensions: functional and emotional, which are referred to as the "total service experience" (Berry et al., 2002). Berry et al. defined the total service experience as the sum of all "clues" offered to the customer during the service provision. They categorized the clues into two types: functional, which relates to the actual functioning of the service, and emotional, which "concerns the emotions and includes the smells, sounds, sights, tastes and textures of the good or service, as well as the environment in which it is offered" (p. 86).

Researchers who characterize service experience as an outcome usually use survey-based quantitative techniques to investigate the linkages between service experience and other service marketing concepts (Helkkula, 2011). Holloway et al. (2005) presented students' online buying experiences as a moderator between service failure and recovery. Similarly, in treating service experience as an outcome, Menon and Bansal (2007) related service experiences to consumer cognition, expectations and emotions.

\subsubsection{Service experience as a phenomenon}

The precursor of the phenomenological characterization of service experience is the argument of Holbrook and Hirschman (1982), who viewed consumption as "conscious experience" (p. 137) with "meanings, hedonic responses and aesthetic criteria" of the consumer. They did not label the phenomenon as a service or goods experience, but described it as "consumption experience". This focus on the consumer understanding of experience is echoed by Carù and Cova (2003), who defined experience as "a subjective episode in the construction/transformation of the individual, with, however, an emphasis on the emotions and senses lived during the immersion at the expense of the cognitive dimension" (p. 273). Helkkula (2011) characterizes service experience phenomenologically as individually and socially determined and subjective in nature. The pivotal work by Vargo and Lusch (2004, 
2008) put forth the Service-Dominant (S-D) logic of marketing, which has contributed to the renewal of characterizing the service experience as a co-created phenomenon.

Service experience has also been claimed to serve as the foundation for the co-creation of value-in-use (Gummerus, 2013; Vargo and Lusch, 2008). This understanding of value-in-use is reflected in the suggested refined concepts of "value as an experience" (Helkkula et al., 2012a) and "value-in-context" (Akaka et al., 2013; Chandler and Vargo, 2011), which are both discussed in value co-creation.

The phenomenological characterization implies that service experiences are "internal, subjective, event-specific and context-specific" in the customers' everyday lives (Helkkula, 2011, p.375). As service experiences may be based on internal experiences, they need be connected to direct experiences, in which a service provider and a customer directly interact with each other (Meyer and Schwager, 2007; Helkkula et al. 2012a). Accordingly, in this paper, we call indirect use experiences those experiences in which a service provider and a customer are not in direct interaction with each other. Some indirect interaction channels are representations of a company's advertising, news reports, reviews, as well as electronic wordof-mouth (Meyer and Schwager, 2007).

A customer that experiences service is part of the service phenomenon. However, the customer may not be in direct contact with the service. For example, a customer might be influenced by being told about the app use experience of another customer. This implies that customers can also use services indirectly (Helkkula and Kelleher, 2010). Therefore, the indirect use experiences, which still occur in customers' everyday lives, should be included in analyzing service experiences.

\subsection{Summary}

In the three characterizations of service experience (outcome, process, and phenomenon), most articles do not distinguish between direct and indirect experiences, except for a few notable exceptions. Meyer and Schwager (2007, pp. 118-119) define experience as “...the internal and subjective response customers have to any direct or indirect contact with a company." They refer to indirect experiences as customer experiences, which happen with the indirect contact of customers with service providers. Helkkula (2011) supports this 
concept, as proposed by Meyer and Schwagger (2007), in arguing for indirect contact as a requisite for indirect experiences. Table 1 shows a compilation of key service experience definitions with phenomenon, process and outcome characterizations, and highlights the distinction between direct and indirect experiences made by only few researchers.

\section{Insert Table 1 here}

Among the three characterizations presented above, this study ascribes service experience as a phenomenon that comprises both direct and indirect use experiences.

\section{Smartphone app use experiences}

In this paper we understand the user as the person who uses the service (i.e. smartphone apps). We do not distinguish between use experience and user experience. We depict use experience as referring to the phenomenologically determined experience in the use of a service. Based on the phenomenological approach, use experience, or user experience, has been scarcely studied, with a few exceptions, such as Payne et al. (2008), and Helkkula and Holopainen (2011).

While use experiences in many studies are restricted to the ongoing consumption of a service and exclude pre-usage (or pre-purchase) and after-usage experiences (Hellén and Gummerus, 2013), customers should also be able to benefit from use experiences outside the current use. In this study, we do not restrict use experiences to only factual, externally observable use.

In contrast to traditional websites, the visibility of apps is system-dependent and affected by the format of the specific app market, such as Apple's App Store or Android's Google Play. Websites are hosted on servers, whereas apps have to be downloaded onto individual user smartphones, and thus they consume the device's memory space. Racherla et al. (2012) identified five dimensions (visibility, accessibility, capability, usability and functionality) in which smartphone apps differ from traditional websites. The access to various apps and their functionality also depends largely on the capabilities of each smartphone. A basic, strippeddown smartphone has fewer enriching graphics and controls for displaying apps, compared with a high-end smartphone, such as the Apple iPhone 6. It should be noted that apps can also download information onto individual smartphones and can function without internet 
connectivity, a feature that is not available for traditional websites. To illustrate, apps that provide navigation services can use preloaded maps and the GPS functionality of the smartphone. Lastly, the functionality of individual apps often differs from their parent websites.

\section{Methodology}

This paper investigates customer use experiences of smartphone apps based on the phenomenological approach, which relates to use experiences that are individually subjective in a social context (Helkkula, 2011). Thompson et al. (1989) argue that phenomenology (in particular, existential phenomenology) is a suitable paradigm for researching consumer experiences. The tenets of existential phenomenology include understanding that experience is contextual, with research goals as thematic descriptions of consumer experiences (Thompson et al., 1989). In accordance with the phenomenological approach, this research is based on the respondents' descriptions and interpretations of their app experiences.

In this study, app-related use experiences are interpreted in a two-phase research design. In the first phase, respondents were asked to write diaries of their experiences while using a specific app. This enables a deep understanding of single app use experience in an experimental setting, in Phase I of empirical study. In Phase II, interviews with the respondents provided data on everyday app use experiences with multiple apps. As customers use multiple apps simultaneously, Phase II of the study required respondent interviews, in which the focus was broadened to include more than one app. Table 2 shows the research design of the data collection methods used in Phase I and Phase II.

\section{Insert Table 2 here}

In this research, the BBC World News app was used to capture respondents' use experiences in the form of diary narratives. The BBC World News app is available on three leading platforms: Apple's App Store, Android's Google Play and Nokia's Ovi Store. These BBC app versions are specifically designed for users outside the United Kingdom (BBC, 2013a; BBC, 2013b) and are available for users globally. Using this app, users can watch news 
videos, read news in text; listen to $\mathrm{BBC}$ radio, and send news content to the $\mathrm{BBC}$ through their smartphones (BBC, 2013a; BBC, 2013b).

In addition to the BBC app, this study includes user's interpretations of their everyday use experiences with a number of apps that they use in their everyday lives. These apps include several well-known apps, such as WhatsApp, Candy Crush Saga, Angry Birds, CamScanner and Facebook. These apps are also available on the three major platforms described above.

\subsection{Phase I (experiment): collecting use experiences with diary narratives}

To understand the phenomenon of customer use experience, we have made use of narratives, which constitute useful data because they reveal the ways in which the respondents make sense of their use experiences (Shankar et al., 2001). The diary research method has emerged as one of the preferred qualitative research methods. It aims to explore a phenomenon by recording the process elements as they happen (Patterson, 2005). The diary research method provides an in-depth understanding of use experiences in real time, which is not possible by other qualitative methods (Bolger et al., 2003). However, the method has been criticized for providing access to a relatively narrow set of narratives (Leipämaa-Leskinen, 2011). We chose to conduct the first phase of data collection using the diary research method in order to gain a deep understanding of app use experiences in an experimental setting. In the exploratory stage, the diary research method can include the purposive sampling of respondents (Siemieniako and Kubacki, 2013).

The respondents were seven business students from the Indian Institute of Foreign Trade, New Delhi, India, and their narratives were recorded in "app diaries" in August 2012. These respondents were purposively selected according to two criteria. First, all the participants were aware, or had prior experience, of watching BBC news and/or documentaries on television and on the BBC website. Second, no participant had used or was aware of the BBC app. These respondents used the BBC World News app during the experiment. The BBC World News app was chosen for the exercise because it offers engagement opportunities through reading news, watching videos and listening to radio news, as well as the option to contribute to $\mathrm{BBC}$ news by sending stories. In addition, the period of the study coincided with the London Olympics in 2012, thus offering multiple opportunities for the study participants to use the app many times each day. Table 3 provides information about the 
participants, including smartphone models, operating systems and the app market from which the BBC World News app was downloaded and used by the students in this study.

\section{Insert Table 3 here}

The respondents downloaded and installed the free app on their phones at the beginning of the exercise. All the respondents possessed a smartphone and used the app every day for seven days. We asked the respondents to write down their experiences of using the smartphone app each day of the exercise, but no directional instructions were given on what to write about their use experiences. The respondents were encouraged to write anything related to the exercise and not to restrict their narratives to usage of the app only. This was done to ensure that details of the participants' lives were also recorded in the diaries because these might affect their experiences with the app (Heinonen et al., 2010). The respondents wrote their experiences in English, and diaries were provided for this purpose. The diaries were collected after the exercise, and the respondent narratives were coded and then saved as separate Word documents. In the analysis of the narratives, they were each read twice in order to familiarize the researchers with the emergent inductive themes of app use experience. Subsequently, the dominant themes of each narrative were compared with other narratives to gain an individual and holistic understanding of the respondent's experiences. Similar narrative themes were categorized into four themes of app use experiences.

\subsection{Phase II: Collecting use experiences via interviews}

Whereas Phase I collected experimental use experiences, Phase II of the study was conducted to interpret app use experiences in the respondents' daily lives. We interviewed the participants to understand their individual experiences with a number of apps in detail (Stokes and Bergin, 2006). In this phase, we used semi-structured interviews to collect data on app use experiences. Semi-structured interviews are an appropriate qualitative research method when the researcher aim is to gain an understanding of the respondents' experiences of a phenomenon (Silverman, 2013). In accordance with the semi-structured format, the interview style was conversational and the interviewer ensured that the key aspects of everyday app use experience were covered. A written interview guide was prepared beforehand (Ayres, 2008) which included interview topics: (a) type of smartphone and app platform, (b) number of apps on phone, (c) name of apps used every day, (d) situations in 
which apps are used, (e) individual or group/family app use experience and (f) experiences, feelings and positive or negative feedback on apps.

The respondents were randomly selected from ordinary smartphone users and were drawn from the same geographical area as the Phase I respondents. All the respondents were bilingual in Hindi and English, and Hindi was their mother tongue. The 23 respondents represented different ages, gender, professions and family situations. All participants used multiple apps in their everyday lives, including gaming, navigation and social media apps. The semi-structured interviews in Phase II of study were conducted in November-December 2013 in India.

In the interviews, the respondents reflected on and talked about their everyday app use experiences. The duration of the interviews was between 16 and 43 minutes. The interviews were conducted in Hindi and subsequently transcribed and translated into English. In the analysis, the interviews were first read individually and then compared with each other. The four analysis themes from Phase I of the study were also used in Phase II. Table 4 presents the details of the interview respondents for Phase II of the study.

\section{Insert Table 4 here}

\section{Findings}

Based on the analysis of the respondents' diaries and interviews, two main types of use experiences emerged from the data, which we labeled direct and indirect use experiences. Direct use experiences included user contact and the actual use of the apps. In contrast to direct use experiences, indirect use experiences included those that did not require the actual use of apps or direct contact with the user. Therefore, indirect use experiences can be imaginary in nature, and thus are a component of phenomenological, holistic service experience and value co-creation (Helkkula et al., 2012b; Meyer and Schwager, 2007; O'Brien, 2004; Valberg, 1992). An example of this phenomenon is the way that a user can vividly imagine a journey or holiday when told by a friend about a travel app and its benefits. We use a four-theme analysis framework to present our findings. 
1) Experienced outcomes from usage of apps (direct and indirect) - the what of app use experience

2) Experienced process of apps usage, (direct and indirect) - the how of app use experience

3) Experienced time in apps usage (direct and indirect) - the when of app use experience

4) Experienced location in using apps (direct and indirect) - the where of app use experiences.

We now present direct and indirect use experiences in these four analysis themes, as gathered from the respondent's diaries and interview.

\subsection{The "what" of use experience: Experienced outcomes}

The "what" of use experience pointed to the outcomes, which the respondents experienced from the direct or indirect use of the apps. The experienced outcomes were multiple and included apps having replaced some other service or relationship, demonstration of increased brand awareness by the respondents, self-reflection on personal identity, and perceived social benefits. These experienced outcomes of app use experiences were both direct and indirect.

\subsubsection{Direct use experiences: Outcomes}

Direct experienced outcomes arose from the direct use of smartphone apps, where the user himself/herself used apps. Govind, one of the diary respondents, described an experienced outcome in the form of an app replacing an existing service. On Day 7, he recorded in his app diary (the days of the exercise on which a particular comment was written down by the respondent in his/her diary are referred as Day 7, Day 1, etc.) that he had stopped his subscription to the paper version of his newspaper, The Hindu. He stopped the newspaper subscription because he now received news content from the BBC app. Thus, the BBC app replaced the existing paper news service to which he had been subscribing.

I have stopped prescribing [sic] for the Hindu Newspaper. Use BBC app, save paper! 
Similarly, Monica, a homemaker, revealed during the interview that the Notebook app on her smartphone had replaced the paper calendar that she had used previously.

I used to make notes on a paper calendar, such as when were my cows vaccinated last time, when did I order cow feed etc. Now I note down these things on my phone, it is much more convenient than the paper calendar. Paper calendar is thrown away every December but my phone stays.

--- Monica, Interview, Direct use experience

All respondents demonstrated a positive reception of the quality of the news delivered by the BBC app. This was partly because of the previous direct use experience of users, which contributed to brand awareness and positive brand judgment of BBC. In addition, the overall outcome quality of the app was perceived as positive, even before the actual use of the app started. Robert noted his judgments about the quality of the news and the app, as follows:

In order to help the researcher, at least I got hold of a good (apparently) app. After all it is BBC's. Can't be that bad.

\section{--- Robert, Day 1, Diary, Direct use experience}

The respondents also related the experienced outcome of the BBC app use to enhancing their personal image in their peer group. The display of their possession of the BBC app increased the prestige of the respondent. A comment by Suresh illustrated the change in self-reflection concerning personal identity.

To look more intellectual and smart I put the app on my phone's homepage. Anyone looking through my phone - well it is hard to ignore the app - would be like "this dude has BBC news app installed on his homepage unlike the others of his age group who just have gaming apps". Well, I can be such a child at times.

--- Suresh, Day 1, Diary, Direct use experience

Phoebe, a working mother, reflected on the changes in her identity and relationships with her family that took place after she started to use Facebook and WhatsApp messenger. She experienced the following outcome from direct use experiences: 
My phone has made me feel a bit unreal lately. I am into chatting, and Facebook. It has become so virtual; it's no longer that personal anymore. Instead of being with my family; I am playing a game or chatting. It makes me a little lazy.

\section{--- Phoebe, Interview, Direct use experience}

Another key experienced outcome from direct use experiences concerned perceived social benefits. The BBC app provided perceived social benefits to the users in acting as a channel for initiating social relationships. Anupam noted the usage of the app as a provider of sports news, which helped him to initiate conversations with female students who were enthusiastic about sports and like to discuss recent sports events.

Browsed through the Olympics page and it helped me strike good conversations with few of the sports enthu [sic] girls of my batch. Thank you BBC App! (-)

--- Anupam, Day 1, Diary, Direct use experience

\subsubsection{Indirect use experiences: Outcomes}

In addition to direct use experiences, the respondents also experienced outcomes from their indirect use experiences of apps. Amy provided an example of indirect use experience, in which an app replaced something else. In this case, Amy described the indirect use experience of her boyfriend relating to the Talking Tom app, which she uses on her phone. She says that her boyfriend was jealous (an experienced outcome) of the virtual cat, Tom, because he felt that he has been replaced by Tom in getting Amy's attention:

My boyfriend is so jealous of Tom! I keep on telling him about what Tom did today and he thinks I love Tom more and I pay him more attention. He has even complained to me that he feels replaced by Tom.

\section{--- Amy, Interview, Indirect use experience of boyfriend}

Mark illustrated an experienced outcome (he perceived himself as smarter) from indirect use experiences in the form of a self-reflection on personal identity. He reflected on his smartness as a potential app user even before buying a smartphone: 
When I first decided to buy a smartphone, I was apprehensive of these new things called apps. Everybody talked about them and said they are awesome. I worried that I am not very technically skilled to handle these new technological things. Then I thought if everybody can use them, then I should be able to use apps as well, I am not less smart than others!

--- Mark, Interview, Indirect use experience

Tajel, an industrial designer, communicated her indirect use experience of apps as the need for maintaining her social status. She felt that as an outcome of owning a smartphone with apps, she could uphold her status in society and avoid diminishing her social reputation. Tajel's comment illustrated the indirect use experience of apps, in which actual contact with apps was not necessary: the mere owning of a smartphone provides social benefits to the user.

I want to maintain a reputation in society and that is why I have a smartphone. Everybody sees your phone and it doesn't look good if you have a small ordinary phone.

--- Tajel, Interview, Indirect use experience

\subsection{The "how" of service experience: Experienced process}

The 'how' theme links direct and indirect use experiences with the experienced service process of apps. Here, the service is experienced as a process with modifiable elements and include experiences in which the respondents made sense of service delivery functions and processes, and of the aesthetics of apps relating to the app interface.

\subsubsection{Direct use experiences: Process}

As a direct use experience, the experienced process of apps focus on the technical features of the app interface, such as, the arrangement of the news tabs, the functional design of the app pages and the video quality. All these experiences relate to the ease of use and/or access to desired information on the app:

I took a pop quiz today. It was fun to take it. They were about the latest happenings in the Pop music scene and pretty genuine also. Overall, it was a good pastime. The app is full with these kinds of 
things which keep you occupied. However, one has to go down the "Menu" to do that. It is not very accessible. I think that a user would not go down to this level "taking a pop quiz", which was fun, unless he is prompted by some highlighting feature on the page.

\section{--- Amit, Day 5, Diary, Direct use experiences}

The direct use experiences relating to service delivery were not independent of the smartphone platform used by the respondent. The experience narratives pointed out the relationship between the technical quality of the app and the platform on which it is delivered. The technical quality of service delivery by apps was affected by the app version (iOS, Android or other), the capabilities of the smartphone on which the app was used, and the speed of the mobile data connection. Suresh wondered whether his smartphone or his telecom service provider (Airtel) was at fault for the slow and interrupted download of the app on Day 1:

While downloading the BBC News app I just realized that either my $H T C$ [supposedly a smartphone] sucks big time or the $2 G$ services of Airtel are at fault. It took me more than 30 minutes to download the app, and cell phone was hanging most of the time while the app was downloading. While believing the latter, I went to Katwaria Sarai to get services upgraded from $2 G$ to $3 G$.

\section{--- Suresh, Day 1, Diary, Direct use experience}

Direct use experiences related to experienced process also included the sense-making of personal experiences in the process of using the app, such as reflecting on one's own aesthetic preferences while using the app interface. Several respondents were pleased with the red color of the BBC app, which served the function of making the app visually appealing and distinguishable during the process of app use.

To begin with, the app looks cool to me. I loved the color combination. The red colored tabs and the ease with which one can jump and navigate the pages is brilliant.

--- Anupam, Day 1, Diary, Direct use experience

\subsubsection{Indirect use experiences: Process}


Experienced process of apps, as indirect use experiences, included the perceived evaluation of the app without direct use. Jacob described his indirect use experience of Angry Birds, a popular app game. He had not yet played the game, but he praised the features of the game, based on peer review:

My friend told me about Angry Birds. I have not played it yet but he told me the story. He also said that the features of the game are pretty amazing; I think it would be cool to play the game on my phone.

\section{--- Jacob, Interview, Indirect use experience}

Luke, a young student, appreciated the design of paid apps compared with that of the free version of the same apps. However, he complained that he could not buy paid apps through his smartphone because he did not have a credit card, and his father would not allow him to use his card. Luke's father had heard from his colleagues that one's credit card information can be compromised when buying apps. Thus, Luke's indirect use experience of app purchasing process was not positive:

Paid apps have better design as compared to the Lite (free) version of the app. I don't buy paid apps, I can't. I don't have a credit card and my dad doesn't allow me to use his [sic]. He is scared his credit card information will be stolen. Someone from his office has told him this.

--- Luke, Interview, Indirect use experience

\subsection{The "when" of service experience: Experienced time}

The experienced time with app use, i.e. the temporal aspect of direct and indirect use experiences was exhibited by the respondents in two ways. The first included the real-time which apps use to update their content (experienced by the users) in synchronization with real-time events. The second includes the time experienced by the user, the way it is scheduled, and the past, present and future subjective experiences of the user. This is also in accordance with the phenomenological characterization of service experience, as propounded by Helkkula (2011) and Vargo and Lusch (2008). The experienced time, similar to the other themes, also involves direct and indirect use experiences. 


\subsubsection{Direct use experiences: Time}

Direct use experiences of apps in real-time refer to the experience of real-time events through synchronized apps. John described his hourly use of the BBC app and how it updated him on the latest information on a football match he was following:

The latest football BBC sport news is the best and considering the transfer season window it has to be followed on nearly an hourly basis. Latest Liverpool FC news is bringing me to the app every hour now.

\section{--- John, Day 6, Diary, Direct use experience}

The direct use experience of time can also be described by users, for example, as 'free time', 'before an afternoon nap' or 'time before sleeping'. The determination of free time not only involved the time slots in a day when the respondent was not otherwise occupied, but also when (s)he is otherwise occupied but could still access and concentrate on the app. The examples included travelling time or during a lecture. Sarah illustrated her direct temporal use experience of the BBC app in the following comments:

Also the app is very useful to keep myself updated when I am travelling or in class or when I have nothing else to do. Hence, this app comes to my rescue when I am attending boring classes. Right now, I am in class!

--- Sarah, Day 6, Diary, Direct use experience

Similarly, Monica enumerated her direct use experience occasions when she schedules her time to play Sudoku and other games on her phone:

I play Sudoku just after my morning tea, also before my afternoon nap. I have to play at least one or two games in the night before I sleep. It has become a habit now and without playing, I don't feel good!

\section{--- Monica, Interview, Direct use experience}

Direct use experiences of time included the experiential transportation of the respondents back or forward in time. The transportation back in time is manifested in the recalling of a past experience or of an entity or event that has not been on the respondent's cognitive radar for some time. Robert remembered Madonna upon reading about her appeal for the Russian 
band Pussy Riot, and he compared the presentation of a news article to a relic from a bygone era.

Read the news about Madonna's appeal for Pussy Riot members' release. Was a long time since I heard anything about the Madonna [sic].

--- Robert, Day 7, Diary, Direct use experience

The whole news section had a black and white era feeling.

--- Robert, Day 6, Diary, Direct use experience

\subsubsection{Indirect use experiences: Time}

Experienced time with indirect experiences is perceived by the users without the direct use of apps. Joseph complained about the frequent news alerts from the news app his friend uses, and wished to have fewer alerts referring to his indirect use experience of real-time app alerts:

It irritates me that my friend's Times of India app buzzes so much with alerts. Does he really need to be so updated with the news? I wish to have a "peaceful" life wherein an app doesn't bother me so much with "breaking news" (sarcasm).

--- Joseph, Interview, Indirect use experience

Victor, an elderly retired respondent, had an indirect use experience, in which he wished to have feature added to his apps. He wanted his apps to remind him when it was time to take his medicines:

I wish apps could tell me when I should take medicines in a day. I need to take medicines 3 times a day and I always forget!

\section{--- Victor, Interview, Indirect use experience}

Also, Victor foretells the future when asked about his app use experiences. He exhibits indirect use experience when he talks about the latest technology he has heard about from his daughter: 
My daughter has also told me about Google glass and its apps. I think in the future, we'll just walk around with these glasses, and all knowledge in the world will be in front of our eyes.

--- Victor, Interview, Indirect use experience.

\subsection{The "where" of service experience: Experienced location}

The "where" theme of direct and indirect use experiences signifies the spatial characteristics of app use. The narratives demonstrated that the "servicescape" (Bitner, 1992) of app experience was not confined to the app window on the user's smartphone but expanded to include the spatial surroundings and the location of the user. The experienced location was manifested in two ways: use experiences relating to the geographical location that the app technically uses in delivering its content, and the use experiences relating to the experienced surrounding location of the user.

\subsubsection{Direct use experiences: Location}

Respondents questioned the customization abilities of the $\mathrm{BBC}$ app in response to the geographic content of news in their direct use experiences. They wondered about the arrangement of news tabs in the app, which had "US and Canada" as news tabs at the beginning of the tab list. The respondents wanted the app to adjust to the geographic location of the users - in this case, India - and automatically place the "Asia" news tab at the beginning of the list.

Categories of US and Canada positioned next to the top stories puzzled me.

\section{--- Robert, Day 1, Diary, Direct use experience}

Since most of the smartphone users have GPS enabled on them, it would be better for the app to realize the location of the user. It would then also come out with relevant information, news and statistics for the user.

--- John, Day 1, Diary, Direct use experience

Direct use experiences also included the experienced surrounding location of the user when using apps. The respondents noted that they used the app in various locations, such as the gym and when travelling: 
Well, one does learn multitasking in MBA life; I was listening to news while running on the treadmill.

--- Suresh, Day 4, Diary, Direct use experience

Diana, a senior lecturer, described her direct use experience of the CamScanner app while travelling:

Even though I have a scanning machine at office, when I am out of office and travelling, I use CamScanner app. It's very convenient and you can use it even on a bumpy road.

--- Diana, Interview, Direct use experience

\subsubsection{Indirect use experiences: Location}

Experienced location with indirect use experiences of apps does not include direct app use. Kevin expressed fondness for historical facts, and he described the imaginary experience of a potential app that he would like to use in the future:

I am a history buff; I like to know about places and what happened there in the past. I wonder if I could use an app which detects the location of the city and tells me about its history, the local history.

--- Kevin, Interview, Indirect use experience

Silvia, a middle-aged working mother and a new smartphone owner, demonstrated her indirect use experience by noting that her smartphone had the capabilities of a small laptop, and it was very convenient for her to carry the phone.

I saw my colleagues taking their smartphones everywhere. Now, I also have a smartphone with apps. I don't use it yet, but it's like a small laptop, a pocket laptop. I'd like to use it while travelling!

--- Silvia, Interview, Indirect use experience

In summary, based on data from the app diaries and the interviews with app users, the phenomenological use experience of apps was delineated into four themes: "what", "how", "when" and "where". As mentioned earlier, the use experience narratives and interviews were not restricted to direct experiences (the actual usage of the app), but also included indirect experiences (requiring no actual app use). Table 5 presents the summary of direct and indirect use experiences with apps. 
Insert Table 5 here

\section{Discussion and conclusions}

Our study focuses on customer service experiences, with a special emphasis on the use experiences of smartphone apps. This paper understands service experience and use experience as a holistic phenomenon, which is individually subjective in a social context and specific event (Lusch and Vargo, 2006; Schembri, 2006). Despite the current research interest in service experience (Ostrom et al., 2010), and the growing importance of the mobile app business, the service literature has not yet focused on apps or their use experiences. To the best of our knowledge, this study is the first attempt to investigate the use experiences of smartphone apps in a service marketing context.

Service experience research has largely overlooked indirect experiences in researching service experience in process, outcome and phenomenon characterizations, except for few studies (Meyer and Schwager, 2007; Helkkula, 2011). We contribute to the service experience literature by proposing that in addition to direct use experiences, indirect use experiences are an important part of the holistic phenomenological service experience. Such indirect use experiences can be triggered when customers listen to the opinions of other customers or are exposed to other forms of communication, such as advertising. For example, a respondent might favorably view a fashion clothing brand when he or she listens to a friend describing the good features of the brand app. The respondent might not use the app, but he or she might positively evaluate the brand because of his or her friend's reviews of the app. Both direct and indirect use experiences relate to the app or to the user, and both are subjective and subject to individual sense-making.

Figure 1 summarizes the direct and indirect use experiences within the themes of what, how, when and where, and shows the outcome, process, temporal and spatial aspects of the use experience. Such question themes are typical in sense-making and reflect how respondents make sense of their app use experiences. The four themes are supported by similar characterizations of service quality (Grönroos, 2007), value (Heinonen, 2004; Heinonen and Strandvik, 2009) and service innovation (Rubalcaba et al., 2012) in the service marketing literature. 
Insert Figure 1 here

In value research, previous studies have shed light on direct (Edvardsson et al., 2010; Grönroos, 2007; Klaus and Maklan, 2012) and indirect interactions (Helkkula et al. 2012a) between customers and service providers in understanding value experiences. While value is experientially determined, indirect value experiences are a relevant part of value co-creation processes (Grönroos and Voima, 2013; Grönroos and Ravald, 2011).

Based on the findings of this study, we conclude that indirect use experiences contribute to value co-creation in app use. Both direct and indirect app use experiences are connected to co-creation of value, even if the main focus has been on direct use experiences. Our findings extend the arguments of Chandler and Vargo (2011) and Vargo et al. (2008) in their criticism that the concept of "use" has been too restrictive and indicative of actual physical use. The criticism has focused primarily on the value-in-use concept, where value is understood as experiential. Grönroos and Voima (2013) have proposed expanding the definition of use beyond physical use to include mental use. Thus, the imaginary use of a service (Helkkula et $a l ., 2012 \mathrm{a}$ ), in which the user visualizes using a service in his/her mind, can also co-create value-in-use. In a similar vein, value-in-context takes the lived lives of users into account (Edvardsson et al., 2011; Gummerus, 2013; Vargo et al., 2008), and the focus is on the context or the surrounding actors and the environment of the user, in determining value-inuse. Value-in-context emphasizes indirect use, in which other parties of the context are involved and not only the direct use value of the user.

To conclude, this paper shows that in addition to direct use experiences, indirect use experiences also contribute to the holistic phenomenological service experience of customers. We argue that customers can experience smartphone apps either by directly or indirectly (e.g. through friends) using an app. Both direct and indirect use experiences affect the experienced process, outcome, time, and location of apps and are thus essential for the cocreation of the service experience.

\subsection{Managerial implications}


Our study has two types of implications for managers. Firstly, although direct and indirect use experiences have similarities, there are differences that need to be taken into account when managers seek to develop their services and facilitate favorable customer use experiences. The differences between direct and indirect use experiences appear lie in the ability of service providers to facilitate or manage customer use experiences and value cocreation. Direct use experiences relate to the user being in direct contact with the app or app service, the technical features of apps, as well as the smartphones themselves. The implication for managers is that service providers have contact with their customers via the apps they provide. For example, app features and smartphone compatibility are relevant factors in use experience, so companies tend to focus on these when developing apps (Hall, 2013).

In indirect use experiences, companies do not have direct access to users or potential users. Most indirect users are unknown to the service provider. However, the indirect user may have very strong value-in-use experiences of an app they have never used. To illustrate, users might evaluate an app such as WebMD, which was designed to provide information about diseases and symptoms, positively in general. However, if a user has just recovered from a stressful health condition, then (s)he might be averse to even hearing about the app and would not evaluate it favorably. Thus, the implication for app developers and managers is that in addition to the direct use experiences, the experiential realms of users and potential users influence their app use experiences. Therefore, managers and app developers should examine the social contexts in which app use experiences take place, as well as how users make sense of their app use experiences.

Secondly, this research argues that customer discernment and appreciation of innovative services are fluid and determined by the customer's personal use experiences. Customers not only discern the outcome of new service concepts as benefits but also are sensitive to the entire use experience phenomenon, which includes the process, temporal and spatial dimensions of experiences. Thus, the strategic aim of service innovation managers (app developers) should be to enable positive use experiences with the innovative features in their services, rather than being restricted to technological or firm-based considerations in designing service innovations (Aarikka-Stenroos and Jaakkola, 2012; Teixeira et al., 2012). Schembri (2006, p. 385) captures this sentiment in claiming, "products, whether they are predominantly goods or services are essentially experiences". 
In summary, this study demonstrates to managers and app developers that although it is important to design excellent technical features of apps, it is also vital to appreciate that apps can be used in a number of ways that lead to both direct and indirect use experiences. Direct use experiences may be managed, but indirect service experiences are beyond the management of service providers and are influenced by the subjective and individual everyday life contexts of users. Based on findings, we encourage service providers to pay attention to both direct and indirect use experiences because both are relevant for the customer's overall holistic use experience and both affect value co-creation.

\subsection{Limitations and further research}

This study used a two-phase research design. The first phase had homogenous respondents, while the second phase included different respondents with a greater variety of life contexts. The number and types of apps covered in this study represent a small fraction of the total number of apps available globally. Further research should use versatile types of research settings with different types of sample groups and a variety of methods to gain a deeper understanding of the influence of individual everyday lives on app use experiences.

This study focuses on a specific type of service experience: use experience. Our findings are related to direct and indirect use experiences, and are based on the thematic questions, what, how, when and where, and therefore cover only a small fraction of the versatile themes in app business. Accordingly we would encourage service researchers to conduct further analysis of the mostly unexplored subject of app use experience. In particular, the social dimension of indirect use experience, such as app experiences within a community or in a specific event, consumer behavior, and, brand-related apps are future areas of research to explore co-created app service experiences. For managerial purposes, future research on indirect use experiences, and how customers co-create value through such experiences, is a vital research area. 


\section{References}

Aarikka-Stenroos, L. and Jaakkola, E. (2012), "Value co-creation in knowledge intensive business services: A dyadic perspective on the joint problem solving process", Industrial Marketing Management, Vol. 41 No. 1, pp. 15-26.

Abrahams, R.D. (1986), "Ordinary and extraordinary experience", in Turner, V.W. and Bruner, E.M. (Eds.), The Anthropology of Experience, University of Illinois Press, Urbana, Illinois, pp. 45-73.

Akaka, M.A., Vargo, S.L. and Lusch, R.F. (2013), “The complexity of context: A service ecosystems approach for international marketing", Journal of International Marketing, Vol. 21 No. 4, pp. 1-20.

Arnould, E. and Price, L. (1993), "River magic: extraordinary experience and the extended service encounter", Journal of Consumer Research, Vol. 20, pp. 24-45.

Ayres, L. (2008), "Semi-structured interview", in Given, L.M. (Ed.), The SAGE Encyclopedia of Qualitative Research Methods, SAGE publications, Inc., Thousand Oaks, California, pp. 811-812.

BBC (2013a), "Your guide to the BBC news android app", available at: http://news.bbc.co.uk/nol/ukfs_news/hi/newsid_9620000/newsid_9626100/9626103.stm (accessed 20 November 2013).

BBC (2013b), "Your guide to the BBC iPhone application", available at: http://news.bbc.co.uk/nol/ukfs_news/hi/newsid_8660000/newsid_8668000/8668044.stm (accessed 20 November 2013).

Bellman, S., Potter, R.F., Treleaven-Hassard, T., Robinson, J.A. and Varan, D. (2011), "The effectiveness of branded mobile phone apps", Journal of Interactive Marketing, Vol. 25, pp. 191-200.

Berry, L.L., Carbone, L.P. and Haeckel, S.H. (2002), "Managing the total customer experience", MIT Sloan Management Review, Spring 2002, pp. 85-89.

Bitner, M.J. (1992), "Servicescapes: The impact of physical surroundings on customers and employees", Journal of Marketing, Vol. 56 No. 2, pp. 57-71. 
Bolger, N., Davis, A. and Rafaeli, E. (2003), "Diary methods: Capturing life as it is lived", Annual Review of Psychology, Vol. 54, pp. 579-616.

Carù, A. and Cova, B. (2003), "Revisiting consumption experience: A more humble but complete view of the concept", Marketing Theory, Vol. 3 No. 2, pp. 267-286.

Chandler, J.D. and Vargo, S.L. (2011), "Contextualization and value-in-context: How context frames exchange", Marketing Theory, Vol. 11 No. 1, pp. 35-49.

Dube, A. (2014), "Becoming happy with “Angry" Birds: customers' phenomenological service experience of virtual games", in Kandampully, J. (Ed.), Customer Experience Management: enhancing Experience and Value through Service Management, Kendall Hunt, Dubuque, IA, pp. 363-368.

Edvardsson, B., Enquist, B. and Johnston, R. (2005), "Cocreating customer value through hyperreality in the prepurchase service experience", Journal of Service Research, Nov. 2005, Vol. 8 No. 2, pp. 149-161.

Edvardsson, B., Enquist, B. and Johnston, R. (2010), "Design dimensions of experience rooms for service test drives: Case studies in several service contexts", Managing Service Quality, Vol. 20 No. 4, pp. 312-327.

Edvardsson, B., Tronvoll, B. and Gruber, T. (2011), "Expanding understanding of service exchange and value co-creation: a social construction approach", Journal of the Academy of Marketing Science, Vol. 39, pp. 327-339.

European Commission (2014), “The $€ 63$ billion app boom. Nearly 5 million jobs in European app sector by 2018, says EU report”, available at: http://europa.eu/rapid/press-release_IP-14145_en.htm (accessed 27 March 2014).

Grönroos, C. (2007), Service Management and Marketing: Customer Management in Service Competition, $3^{\text {rd }}$ edition, John Wiley and Sons Ltd., Chichester.

Grönroos, C. and Voima, P. (2013), "Critical service logic: making sense of value creation and co-creation", Journal of the Academy of Marketing Science, Vol. 41 No. 2, pp. 133-150.

Grönroos, C. and Ravald, A: (2011), "Service as business logic: implications for value creation and marketing”, Journal of Service Management, Vol. 22 No. 1, pp. 5-22. 
Gummerus, J. (2013), "Value creation processes and value outcomes in marketing theory: Strangers or siblings?", Marketing Theory, Vol. 13 No. 1, pp. 19-46.

Hall, B. (2013), "Your app is not sticky enough", available at: http://www.ideatoappster.com/your-app-is-not-sticky-enough/ (accessed 12 December 2013).

Heinonen, K. (2004), "Reconceptualizing customer perceived value - the value of time and place", Managing Service Quality, Vol. 14 Nos. 2/3, pp. 205-215.

Heinonen, K. and Strandvik, T. (2009), "Monitoring value-in-use of e-service", Journal of Service Management, Vol. 20 No. 1, pp. 33-51.

Heinonen, K., Strandvik, T., Mickelsson, K.J., Edvardsson, B., Sundström, E. and Andersson, P. (2010), "A customer-dominant logic of service", Journal of Service Management, Vol. 21 No. 4, pp. 531-548.

Helkkula, A. (2011), "Characterising the concept of service experience", Journal of Service Management, Vol. 27 No. 3, pp. 367-389.

Helkkula, A. and Holopainen, C. (2011), "Service innovation as an experience: differences between employee and user narratives", in Sundbo, J. and Toivonen, M. (Eds.), User-Based Innovation in Services, Edward Elgar, Cheltenham, UK, Manchester, USA, pp. 281-302.

Helkkula, A. and Kelleher, C. (2010), "Circularity of customer service experience and customer perceived value", Journal of Customer Behaviour, Vol. 9 No.1, pp. 37-53.

Helkkula, A., Kelleher, C. and Pihlström, M. (2012a), "Characterizing value as an experience: Implications for service researchers and managers", Journal of Service Research, Vol. 15 No. 1, pp. 59-75.

Helkkula, A., Kelleher, C. and Pihlström, M. (2012b), "Practices and experiences: Challenges and opportunities for value research", Journal of Service Management, Vol. 23 No. 4, pp. $554-570$.

Hellén, K. and Gummerus, J. (2013), "Re-investigating the nature of tangibility/intangibility and its influence on consumer experiences”, Journal of Service Management, Vol. 24 No. 2, pp. $130-150$. 
Holbrook, M.B. and Hirschman, E.C. (1982), "The experiential aspects of consumption: Consumer fantasies, feelings and fun”, Journal of Consumer Research, Vol. 9, pp. 132-140.

Holloway, B.B., Wang, S. and Parish, J.T. (2005), "The role of cumulative online purchasing experience in service recovery management", Journal of Interactive Marketing, Vol. 19 No. 3, pp. 54-67.

Johnston, R. and Clark, G. (2001), Service Operations Management, Prentice Hall, London.

Kellogg, D. (2011), "Mobile apps beat the mobile web among US android smartphone users", available at: http://www.nielsen.com/us/en/newswire/2011/mobile-apps-beat-the-mo (accessed 3 February, 2014).

Klaus, P. and Maklan, S. (2012), "EXQ: a multiple-item scale for assessing service experience”, Journal of Service Management, Vol. 23 No. 1, pp. 5-33.

LaSalle, D. and Britton, T.A. (2003), Priceless: Turning Ordinary Products into ExtraOrdinary Experiences, Harvard Business School Press, Boston.

Leipämaa-Leskinen, H. (2011), “Cultural analysis of dieting consumers' construction of bodies and identities", Qualitative Market Research: An International Journal, Vol. 14 No. 4, pp. $360-373$.

Lovelock, C. and Wirtz, J. (2007), Services Marketing: People, Technology, Strategy, $6^{\text {th }}$ edition, Pearson/Prentice Hall, Upper Saddle River, New Jersey.

Lusch, R. F. and Vargo, S.F. (2006), "Service-dominant logic: reactions, reflections and refinements", Marketing Theory, Vol. 6 No. 3, pp. 281-288.

Menon, K. and Bansal, H.S. (2007), "Exploring consumer experience of social power during service consumption", International Journal of Service Industry Management, Vol. 18 No. 1, pp. 89-104.

Meyer, C. and Schwager, A. (2007), "Understanding customer experience", Harvard Business Review, February, pp. 117-126.

Monti, E. (2013), "Million dollar expense: Buying out the App Store", available at: http://gigaom.com/2013/09/29/million-dollar-expense-buying-out-the-app-store/ (accessed 7 October 2013). 
O'Brien, D. (2004), "The epistemology of perception", available at: http://www.iep.utm.edu/e/epis-per.htm\#SH3c (accessed 22 November 2013).

Ostrom, A.L., Bitner, M.J., Brown, S.W., Burkhard, K.A., Goul, M., Smith-Daniels, V., Demirkan, H. and Rabinovich, E. (2010), "Moving forward and making a difference: Research priorities for the science of service”, Journal of Service Research, Vol. 13 No. 1, pp. 4-36.

Pareigis, J., Echeverri, P. and Edvardsson, B. (2012), "Exploring internal mechanisms forming customer servicescape experiences", Journal of Service Management, Vol. 23 No. 5, pp. 677-695.

Pareigis, J., Edvardsson, B. and Enquist, B. (2011), "Exploring the role of the service environment in forming customer's service experience", International Journal of Quality and Service Sciences, Vol. 3 No. 1, pp. 110-124.

Patricio, L., Fisk, R.P., Cunha, J.F. and Constantine, L. (2011), "Multilevel service design: From customer value constellation to service experience blueprinting", Journal of Service Research, Vol. 14 No. 2, pp. 180-200.

Patterson, A. (2005), "Processes, relationships, settings, products and consumers: the case for qualitative diary research", Qualitative Market Research: An International Journal, Vol. 8 No. 2, pp. 142-156.

Payne, A., Storbacka, K. and Frow, P. (2008), "Managing the co-creation of value", Journal of the Academy of Marketing Science, Vol. 36, No. 1, pp. 83-96.

Pine, B.J. and Gilmore, J.H. (1998), "Welcome to the experience economy", Harvard Business Review, July-August, pp. 97-105.

Pine, B.J. and Gilmore, J.H. (1999), The Experience Economy: Work is Theatre and Every Business a Stage, Harvard Business School Press, Cambridge, MA.

Racherla, P., Furner, C. and Babb, J. (2012), "Conceptualizing the implications of mobile app usage and stickiness: A research agenda", available at: http://ssrn.com/abstract=2187056 (accessed 29 September 2013).

Reimer, A. and Kuehn, R. (2005), "The impact of servicescape on quality perception", European Journal of Marketing, Vol. 39 Nos. 7/8, pp. 758-808. 
Rubalcaba, L., Michel, S., Sundbo, J., Brown, S.W. and Reynoso, J. (2012), "Shaping, organizing, and rethinking service innovation: a multidimensional framework", Journal of Service Management, Vol. 23 No. 5, pp. 696-715.

Sandström, S., Edvardsson, B, Kristensson, P. and Magnusson, P. (2008), "Value in use through service experience", Managing Service Quality, Vol. 18 No.2, pp. 112-126.

Schembri, S. (2006), "Rationalizing service logic, or understanding services as experience?”, Marketing Theory, Vol. 6 No. 3, pp. 381-392.

Schmitt, B.H. (1999), Experiential marketing: How to get customers to SENSE, FEEL, THINK, ACT and RELATE to your company and brands, The Free Press, New York.

Shankar, A., Elliott, R. and Goulding, C. (2001), "Understanding consumption: Contributions from a narrative perspective", Journal of Marketing Management, Vol. 17, pp. 429-453.

Siemieniako, D. and Kubacki, K. (2013), "Female students' drinking seen through collages and diaries", Qualitative Market Research: An International Journal, Vol. 16 No. 3, pp. 296314.

Silverman, D. (2013), "Issues in research design", in Doing Qualitative Research: A Practical Handbook, SAGE publications, Inc., Thousand Oaks, California, pp. 43-68.

Stokes, D. and Bergin, R. (2006), "Methodology or "methodolatry"? An evaluation of focus groups and depth interviews", Qualitative Market Research: An International Journal, Vol. 9 No. 1, pp. 26-37.

Teixeira, J., Patricio, L., Nunes, N.J., Nobrega, L., Fisk, R.P. and Constantine, L. (2012), "Customer experience modelling: from customer experience to service design", Journal of Service Management, Vol. 23 No. 3, pp. 362-376.

Thompson, C., Locander, W. and Pollio, H. (1989), "Putting consumer experience back into consumer research: The philosophy and method of existential-phenomenology", Journal of Consumer Research, Vol. 16 No. 2, pp. 133-146.

Troianovski, A. (2013), "Apps: The new corporate cost-cutting tool”, available at: http://online.wsj.com/news/articles/?mg=reno64wsj\&url=http\%3A\%2F\%2Fonline.wsj.com\%2Farticle\%2FSB1000142412788732467860457 834269 (accessed 7 April, 2013). 
Valberg, J.J. (1992), The Puzzle of Experience, Clarendon Press, Oxford University Press, Oxford.

Vargo, S.L. and Lusch, R.F. (2004), "Evolving to a new dominant logic for marketing", Journal of Marketing, Vol. 68 No. 1, pp. 1-17.

Vargo, S.L. and Lusch, R.F. (2008), "Service-dominant logic: Continuing the evolution", Journal of the Academy of Marketing Science, Vol. 36, pp. 1-10.

Vargo, S.L., Maglio, P.P. and Akaka, M.A. (2008), "On value and value co-creation: A service systems and service logic perspective", European Management Journal, Vol. 26, pp. $145-152$. 
Table 1: Service experience definitions and their characterizations

\begin{tabular}{|c|c|c|}
\hline Definition & Author/s & Characterization \\
\hline $\begin{array}{l}\text { "Primarily subjective state of consciousness } \\
\text { with a variety of symbolic meanings, hedonic } \\
\text { responses and aesthetic criteria" }\end{array}$ & $\begin{array}{l}\text { Holbrook and Hirschman } \\
(1982, \text { p. 132) }\end{array}$ & Phenomenon \\
\hline $\begin{array}{l}\text { "... service encounter research increasingly } \\
\text { recognizes that service experience is } \\
\text { inherently interpretive, subjective, and } \\
\text { affective" }\end{array}$ & $\begin{array}{l}\text { Arnould and Price } \\
\quad(1993, \text { p. 28) }\end{array}$ & Phenomenon \\
\hline $\begin{array}{l}\text { "... experiences are inherently personal, } \\
\text { existing only in the mind of an individual } \\
\text { who has been engaged on an emotional, } \\
\text { physical, intellectual, or even spiritual level" }\end{array}$ & $\begin{array}{l}\text { Pine and Gilmore } \\
(1998, \text { p. 99) }\end{array}$ & $\begin{array}{c}\text { Phenomenon and } \\
\text { Process }\end{array}$ \\
\hline $\begin{array}{l}\text { "Experience is defined as a subjective } \\
\text { episode in the construction/transformation of } \\
\text { the individual, with, however, an emphasis on } \\
\text { the emotions and senses lived during the } \\
\text { immersion at the expense of the cognitive } \\
\text { dimension" }\end{array}$ & $\begin{array}{l}\text { Carù and Cova } \\
(2003, \text { p. } 273)\end{array}$ & Phenomenon \\
\hline $\begin{array}{l}\text { "We define a service experience as a service } \\
\text { process that creates the customer's cognitive, } \\
\text { emotional, and behavioral responses, } \\
\text { resulting in a mental mark, a memory" }\end{array}$ & $\begin{array}{l}\text { Edvardsson et al. } \\
(2005, \text { p. 151) }\end{array}$ & Process \\
\hline $\begin{array}{l}\text { "... it is argued that services are dynamic } \\
\text { experiences, co-constructed with customers } \\
\text { in accordance with their views" }\end{array}$ & $\begin{array}{c}\text { Schembri } \\
(2006, \text { p. } 386)\end{array}$ & Phenomenon \\
\hline $\begin{array}{l}\text { "A service experience is the sum total of the } \\
\text { functional and emotional outcome } \\
\text { dimensions of any kind of service" }\end{array}$ & $\begin{array}{l}\text { Sandström et al. } \\
(2008, \text { p. 118) }\end{array}$ & Outcome \\
\hline $\begin{array}{l}\text { "The term "service experience" refers to the } \\
\text { customer's personal experience of the service } \\
\text { process as a result of interactions with the } \\
\text { service organization and its frontline staff, } \\
\text { facilities, and technology" }\end{array}$ & $\begin{array}{l}\text { Edvardsson et al. } \\
\text { (2010, p. 313) }\end{array}$ & Process \\
\hline $\begin{array}{l}\text { "... the internal and subjective response } \\
\text { customers have to any direct or indirect } \\
\text { contact with a company." }\end{array}$ & $\begin{array}{l}\text { Meyer and Schwager } \\
\quad(2007, \text { p. 118) }\end{array}$ & $\begin{array}{l}\text { Phenomenon (Direct } \\
\text { and Indirect) }\end{array}$ \\
\hline $\begin{array}{l}\text { "... individual experiences }- \text { which are } \\
\text { usually internal, subjective, event-specific } \\
\text { and context-specific" }\end{array}$ & $\begin{array}{c}\text { Helkkula } \\
(2011, \text { p. } 375)\end{array}$ & $\begin{array}{l}\text { Phenomenon (Direct } \\
\text { and Indirect) }\end{array}$ \\
\hline
\end{tabular}


Table 2. Research design for data collection

\begin{tabular}{cccccc}
\hline Phase & Method & $\begin{array}{c}\text { Type of use } \\
\text { experiences }\end{array}$ & $\begin{array}{c}\text { No. of apps } \\
\text { experienced }\end{array}$ & $\begin{array}{c}\text { Type of } \\
\text { respondents }\end{array}$ & $\begin{array}{c}\text { No. of } \\
\text { respondents }\end{array}$ \\
\hline Phase I & Diaries & $\begin{array}{c}\text { Experiences in an } \\
\text { experiment setting - } \\
\text { identifying themes }\end{array}$ & One app & $\begin{array}{c}\text { Homogeneous } \\
\text { sample of } \\
\text { respondents }\end{array}$ & 7 \\
Phase & Interviews & $\begin{array}{c}\text { Everyday life } \\
\text { experiences - } \\
\text { identifying and } \\
\text { further analyzing } \\
\text { themes }\end{array}$ & Several apps & $\begin{array}{c}\text { Heterogeneous } \\
\text { sample of } \\
\text { respondents }\end{array}$ & 23 \\
\hline
\end{tabular}

Table 3: Phase I BBC World News app use experience respondents

\begin{tabular}{ccccc}
\hline Number & Name* & Gender & Phone Brand & App Platform \\
\hline & & & & \\
1. & Robert & Male & HTC Explorer & Android \\
2. & Sarah & Female & iPhone 4.0 & iOS \\
3. & Amit & Male & BlackBerry 8520 & BlackBerry \\
4. & Suresh & Male & HTC Wildfire & Android \\
5. & David & Male & Nokia N8 & Symbian \\
6. & John & Male & Sony Xperia Neo V & Android \\
7. & Anupam & Male & Samsung Galaxy S2 & Android \\
& & & & \\
\hline
\end{tabular}

*Names have been changed 
Table 4. Phase II app use experience interview respondents

\begin{tabular}{|c|c|c|c|c|c|c|c|c|}
\hline $\begin{array}{c}\text { Num } \\
\text { ber }\end{array}$ & Name* & Gender & Age & Phone Brand & $\begin{array}{c}\text { App } \\
\text { Platform } \\
\end{array}$ & Education & Profession & Family Situation \\
\hline 1. & John & Male & 20 & Samsung Galaxy Grand & Android & Bachelors (pursuing) & Student & Single \\
\hline 2. & Alex & Male & 29 & Google Nexus 4 & Android & Bachelors & $\begin{array}{l}\text { Innovation Manager } \\
\text { (Manufacturing) }\end{array}$ & Married \\
\hline 3. & Tajel & Female & 26 & Samsung Galaxy S3 & Android & Masters & Industrial Designer & Engaged \\
\hline 4. & Monica & Female & 60 & Samsung Galaxy Note & Android & Bachelors & Homemaker & $\begin{array}{l}\text { Married, } \\
\text { Grandmother }\end{array}$ \\
\hline 5. & Phoebe & Female & 31 & iPhone 5 & iOS & Bachelors & IT Engineer (Mobile UI Designer) & Single, Mother \\
\hline 7. & Ann & Female & 26 & Sony Xperia Neo & Android & MBA & Manager (Manufacturing) & Single \\
\hline 8. & Carl & Male & 33 & Xolo Q800 & Android & Masters & Lecturer (Maths) & Married, Father \\
\hline 9. & Joseph & Male & 30 & Nokia Lumia 910 & Windows & Masters & Computer Programmer & Married, Father \\
\hline 10. & Tom & Male & 17 & Samsung Galaxy Ace S5830I & Android & School & Pupil & Single \\
\hline 11. & Ben & Male & 16 & Samsung Galaxy Mega & Android & School & Pupil & Single \\
\hline 12. & Luke & Male & 15 & Samsung Galaxy Grand & Android & School & Pupil & Single \\
\hline 13. & Silvia & Female & 42 & Micromax Canvas & Android & Masters & Research Officer & $\begin{array}{l}\text { Married, } \\
\text { Mother }\end{array}$ \\
\hline 14. & Betty & Female & 38 & Samsung Galaxy Grand & Android & Masters & Lecturer & $\begin{array}{l}\text { Married, } \\
\text { Mother }\end{array}$ \\
\hline 15. & Mark & Male & 27 & Samsung Galaxy & Android & Bachelors & Assistant Teacher & Single \\
\hline 16. & Mike & Male & 24 & Samsung Galaxy 4, Akash Tablet & Android & Bachelors & Assistant Teacher & Single \\
\hline 17. & Harry & Male & 23 & Karbonn A4 plus & Android & Bachelors & Undergoing teaching training & Single \\
\hline 18. & Kevin & Male & 25 & Samsung Galaxy 4 & Android & Bachelors & Undergoing teaching training & Single \\
\hline 19. & Cecilia & Female & 24 & Nokia Lumia & Windows & Masters & Undergoing teaching training & Married \\
\hline 20. & Victor & Male & 71 & Karbonn Titanium, iPhone 4 & $\begin{array}{l}\text { Android, } \\
\text { iOS }\end{array}$ & Bachelors & $\begin{array}{c}\text { Retired Pharmaceutical Sales } \\
\text { Manager }\end{array}$ & $\begin{array}{l}\text { Married, } \\
\text { Grandfather }\end{array}$ \\
\hline 21. & Adam & Male & 29 & Samsung gt19000 & Android & MBA & Business Journalist & In a relationship \\
\hline 22. & Diana & Female & 58 & $\begin{array}{c}\text { Micromax Phone, Samsung Galaxy } \\
\text { Tab, Samsung Phone }\end{array}$ & Android & Masters & Senior Lecturer & $\begin{array}{l}\text { Married, } \\
\text { Mother }\end{array}$ \\
\hline 23. & Amy & Female & 28 & iPhone 4S & iOS & Masters & Researcher & In a relationship \\
\hline
\end{tabular}

*Names have been changed 
Table 5. Four themes of direct and indirect use experiences

\begin{tabular}{|c|c|c|c|}
\hline $\begin{array}{c}\text { What } \\
\text { (Experienced Outcomes) }\end{array}$ & $\begin{array}{c}\text { How } \\
\text { (Experienced Process) }\end{array}$ & $\begin{array}{c}\text { When } \\
\text { (Experienced Time) }\end{array}$ & $\begin{array}{c}\text { Where } \\
\text { (Experienced Location) }\end{array}$ \\
\hline $\begin{array}{l}\text { - App replaces an existing } \\
\text { service/relationship: } \\
\text { e.g., news apps replace newspapers (*D), } \\
\text { virtual pet apps replace existing } \\
\text { relationships (**I) } \\
\text { - Increased awareness of a specific } \\
\text { brand: } \\
\text { e.g., game app use increases awareness } \\
\text { about the gaming brand (D), } \\
\text { people become more aware of a clothing } \\
\text { brand when they hear about their friends' } \\
\text { app experiences (I) } \\
\text { - Self-reflection on personal identity: } \\
\text { e.g. use of news apps makes users feel } \\
\text { smarter (D), } \\
\text { just ownership without actual use of news } \\
\text { apps makes the owner feel smarter (I) } \\
\text { - Social benefits: } \\
\text { e.g., use of certain apps helps users form } \\
\text { social bonds (D), } \\
\text { just ownership of a smartphone with apps } \\
\text { without using them increases the social } \\
\text { reputation of a user (I) }\end{array}$ & $\begin{array}{l}\text { - Evaluation of app functions } \\
\text { during the process of use: } \\
\text { e.g., users frequently } \\
\text { evaluate app functions while } \\
\text { using them (D), } \\
\text { users frequently evaluate } \\
\text { app functions when they } \\
\text { observe other users for a } \\
\text { period of time (I) } \\
\text { - Evaluation of aesthetic } \\
\text { preferences during the } \\
\text { process of use: } \\
\text { e.g., users frequently } \\
\text { evaluate the design of apps } \\
\text { during the process of use } \\
\text { (D), } \\
\text { users frequently evaluate the } \\
\text { design of apps when they } \\
\text { observe other users for a } \\
\text { period of time (I) }\end{array}$ & $\begin{array}{l}\text { - Experience of real-time events: } \\
\text { e.g., users experience real-time } \\
\text { entertainment content through apps } \\
\text { (D), } \\
\text { users indirectly experience real- } \\
\text { time entertainment content when } \\
\text { friends update them on the latest } \\
\text { events (I) } \\
\text { - Use of apps affects the experience } \\
\text { of time and how it is scheduled: } \\
\text { e.g., users play app games during } \\
\text { specific hours in a day (D), } \\
\text { users wish to use a scheduling app } \\
\text { that reminds them of the activities } \\
\text { to be done at a specific time of the } \\
\text { day (I) } \\
\text { - Experience of past events: } \\
\text { e.g., users reminisce about a past } \\
\text { event upon reading about it } \\
\text { through an app (D), } \\
\text { users are temporally transported } \\
\text { into the past or future without } \\
\text { direct app use, such as when } \\
\text { talking with a friend (I) }\end{array}$ & $\begin{array}{l}\text { - Experience of location: } \\
\text { e.g., users like apps that } \\
\text { update according to the } \\
\text { geographical location of } \\
\text { the users (D) } \\
\text { users wish to use or hear } \\
\text { about other user } \\
\text { experiences of apps that } \\
\text { provide location-specific } \\
\text { information (I) } \\
\text { - Experience of the users, } \\
\text { surrounding location: } \\
\text { e.g., users use apps in } \\
\text { certain specific locations, } \\
\text { such as while travelling } \\
\text { in a bus (D), } \\
\text { users wish to use or hear } \\
\text { about other user } \\
\text { experiences of apps in } \\
\text { various locations (I) }\end{array}$ \\
\hline
\end{tabular}

*Direct use experience, **Indirect use experience 


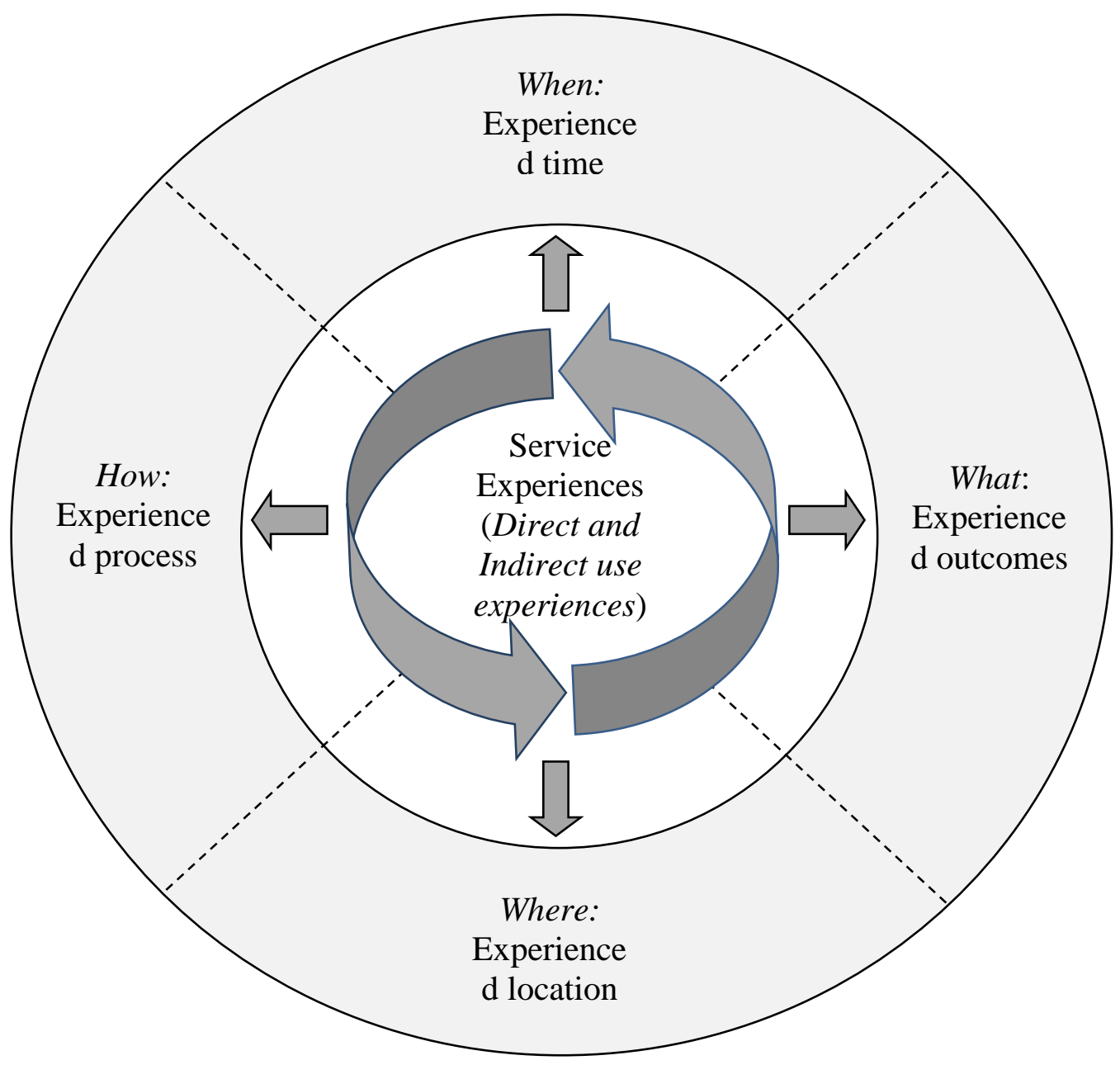

Figure 1. Service experience with direct and indirect use experience of smartphone apps 